\title{
Study on the Teaching Situation and Development Strategy of College
}

\section{Sports Network}

\author{
Qing $\mathrm{Li}^{1}$, Dandan Han ${ }^{2}$ \\ ${ }^{1}$ Sports Department, Nanchang Institute of Science and Technology, Nanchang Jiangxi, 330108 \\ 346591653@163.com
}

KEYWORDS: PE; Network teaching; Status; Policy

\begin{abstract}
With the continuous development of computer technology, networking, digital, information technology network teaching has become an inevitable trend of modern college physical education. College Sports network instruction can make better use of the various sports teaching resources, improve resource utilization, and promote students' physical learning outside the classroom curriculum and improve student learning enthusiasm and initiative to a great extent, enhance their sporting qualities. Now present, although our college sports network teaching has made some achievements, but still there are some problems. This paper describes the current situation of university education network, and then analyzes the problems of teaching sports network, on the basis of the above, put forward relevant countermeasures.
\end{abstract}

\section{Introduction}

Teaching computer is network teaching and multimedia teaching. Network teaching is a new teaching method advocated by the international community is now present, it is for students to create an illustrated, very impressive and vivid learning environment, conducive to the smooth implementation of the teacher teaching the image, effectively stimulate students' interest in learning, improve teaching effectiveness. Network teaching with respect to traditional teaching, has the following advantages: 1 , the network and intuitive new teaching methods, the image can be effectively utilized scenarios demonstrate stimulate student interest in learning, further development potential of students, enrich the content of teaching, active classroom atmosphere. Second, the students explore effective use of network learning autonomous learning. Physical education curriculum is contemporary integral part of higher education, in favor of the students' overall development, innovative teaching mode, improve the quality of teaching sports, so the introduction of Network Teaching in College Physical Education is very necessary. Now present, compared with the international, the College Sports Network Education China is still in its infancy, there are many places lack, which is not conducive to China's sports teaching information technology, modernization, and therefore how to improve the teaching mode innovation networks sport is our teaching problems to be solved.

\section{The Status of College Sports Network Education}

Network Teaching in Higher Education has gradually gained in importance, has achieved initial results. Many of our colleges and universities have begun to adopt teaching, and made the corresponding planning and training. According to relevant survey: Beijing University of Physical 
Education, Chengdu Institute of Physical Education, Wuhan Institute of Physical are making the construction of interactive network teaching platform. Sports Collectibles to build some of the schools curriculum into the school building quality track and sports write textbooks and educational software based on the actual needs of students, the establishment of courses, in order to better fit the students' interests and hobbies. Now, part of the Sports Network Quality Course Construction in China has made some achievements, such as sports and martial arts health science courses Chengdu Institute of Physical Education was named the first batch of Sichuan Province quality courses. To make our sport more online teaching excellence, a plurality of College Sports Network to achieve the teaching content sharing, improve resource utilization, network courses systematized. School authorities cooperate with each other to create a sports network teaching platform, students can visit freely select the content they are interested in learning, improve learning efficiency.

\section{Second, the problem of teaching College Sports Network}

\section{A. Lack of Attention to Online Teaching Degree}

With the popularity of online teaching, many colleges and universities are increasingly aware of the importance of Physical Teaching. But it is undeniable that the current PE teaching now most of our universities or traditional education, they did not recognize the importance of physical education network, the school network teaching resources and manpower, lack of network quality courses. Course of College Sports Network now or in the direct teaching of teachers teaching methods based, but the network as a simple way of teaching, low utilization, passive participation in the process of teaching students, students rarely driven initiative. This is very easy for students that teaching boring Sports Network, the curriculum as a task is completed, did not excite the enthusiasm of students, which is the target of online teaching is a far cry from the true sense.

\section{B. Lack of Teaching Resources and the Quality is not High}

Our Sports Network Teaching implementation time is not long, it did not form a mature network teaching system. Most of China's sports network teaching methods and content are from abroad, some content does not meet the actual situation of College Physical Education in China, it needs further improvement and innovation. Sports insufficient teaching courseware, teaching resources, mostly from existing online database, and the quality is not high, and even some school directly to the teachers directly as a network video courseware. Now my current network teaching content is mainly teacher speaker, plus after-school answer, or video and text, students are not able to talk between teachers and students interact effectively discuss, low depth of knowledge and learning. Network teaching textbook content is basically a replica, not to widen knowledge, knowledge and repetitive students not interested in online teaching and that it did not play any role.

\section{Low Network Teaching Quality of Teachers}

Network teaching has now become an inevitable trend of higher learning currently teaching, in order to promote the rapid pace of network teaching, the need for a large number of network ability to use high-quality teachers to support groups. Network Teaching in Physical Education Instructional applied to our time is short, the lack of professional quality of teachers groups, seriously hindered the healthy development of university sports network teaching. China is now the current college sports teachers low level of computer technology, you can only use a simple image and text production, low capacity for animation Courseware. According to the survey: My College is now faced with the dilemma with the lack of computer and network technology talent, college sports teachers with less than $10 \%$ of online teaching technique. 


\section{Unscientific Evaluation Mode}

Science teaching and evaluation mode is to support the teaching of College Sports Network foundation. College Sports Network Teaching Mode of the single, most students take independent watch an instructional video for the main way, students' motivation to learn is very low, we can not mobilize students autonomy. Sports Network Teaching Evaluation unreasonable, there is a lack of specific evaluation, evaluation model and the way a single issue. Now, teaching evaluation of college sports network mostly for teaching content, and lack of teacher evaluation. After the tutorial is a way to detect exam answer students' learning outcomes, single way, so that the lack of independent learning and interactive discussions attention, this traditional sports teaching consistent.

\section{The Relevant Development Strategy of Teaching College Sports Network}

Sports Network Teaching reason with low level of development in a short time to promote our country, most people lack of knowledge of network teaching has a great relationship. In response to this situation, major colleges and universities to enhance the emphasis on teaching, teaching concepts change the original, so that network teaching and traditional teaching combine to promote the healthy development of university sports teaching. School teachers and students to enhance understanding of the sports network teaching through lectures, media, etc., to eliminate their prejudice against Teaching. Schools should be teaching into the school network development plan, and create a harmonious network teaching environment and promote the effective implementation of online teaching.

Unlike traditional network curriculum teaching, professor teacher knowledge is mostly transient, which requires the teaching content streamlined, flexible manner, to facilitate students to quickly understand. Requiring schools to intensify excellent course, actively using computer technology, flexible use of network resources, teaching content so that students more quickly and vividly understand the course content, the traditional teaching methods can not copy the network teaching, really inspire students interest in learning, improve efficiency. It should be established between the university network education share, increase cooperation between schools together for physical education for college and work.

Network teaching is the current low level of teachers currently teaching imprison the Development of College Sports Network's one of the important reasons. Therefore, our country must pay attention to computer technology training PE teachers to enable them to skillfully use networks and multimedia equipment, master courseware, animation and other skills, in order to ensure the smooth conduct of online teaching. School sports should increase investment in network construction and education, PE teachers actively encourage it to school to learn and training, to strengthen the teacher's computer skills training and upgrading.

College Sports Network Education must set appropriate learning evaluation system, students and teachers to mobilize the enthusiasm and interest. College Sports Network now currently teaching our students only concerned about the evaluation of the final grade, while the network is a dynamic process of teaching more courses should focus on the process of evaluation of the network, to understand students' learning status and learning attitude. Evaluation can not be confined to the main teaching content should also be concerned about the teachers and the students themselves, and to adjust the teaching content and methods to meet the various needs of students' learning process. 


\section{Conclusion}

Network technology and the rapid development of multimedia technology effectively broaden the channels of college physical education, sports teaching to bring both opportunities and challenges. To do a good job teaching sports network in the Cyber background, requires us to smoothly requirements of the times, the rational use of modern network technology to build a high-quality modern teachers, innovative online teaching content and grasp the characteristics of Physical Education, training high modern talent quality.

\section{References}

[1] Xu Bihong. Subject Construction of College Physical Engineering Study [D]. China University of Mining, 2012.

[2] Liu Ting. Situation of College Students Sports and Media Literacy Education Strategy Research [D]. Capital Institute of Physical Education, 2013.

[3] Yang Jiayue. College Sports Network Education Development Dilemma aAnd Countermeasures [J]. Education Guide (Late), 2015,12: 85-86. 